\title{
MELANISM IN BISTON (LEPIDOPTERA: GEOMETRIDAE) IN THE RURAL CENTRAL APPALACHIANS
}

\author{
DAVID A. WEST \\ Department of Biology, Virginia Polytechnic Institute and State University, Blacksburg, Virginia 2406 I
}

Received 11.x.76

\begin{abstract}
Summary
The melanic swettaria form of Biston betularia cognataria is at low frequency in two localities in the central Appalachians of southwest Virginia $(1 \cdot 2 \pm 0.2$ per cent at Blacksburg and $2 \cdot 9 \pm 0.4$ per cent at Mountain Lake). The presence of swettaria is probably the result of widespread air pollution from industrial regions to the west and east, but physiological selection is more likely than selection by predators, since the environments of the collecting localities have not been visibly altered. Form swettaria is dominant to typical in these populations, and the intermediate insularia $a^{5}$ phenotype appears also to be dominant. The carbonaria phenotype of Old World betularia retains its dominance through three backcross generations to typicals from these same populations.
\end{abstract}

\section{INTRODUGTION}

The North American geometrid moth Biston betularia cognataria (Guenée), like its European counterpart $B . b$. betularia L, has responded to industrial pollution by an increase in the frequency of melanic forms, especially form swettaria Barnes and McDunnough, which is phenotypically indistinguishable from the carbonaria form of $B$. b. betularia (Kettlewell, 1973). In eastern North America cognataria ranges from Canada south to Missouri, Kentucky and New Jersey, and in the Appalachians at least as far as the southern border of North Carolina (Rindge, 1975; West, unpubl. observations). In the northern states Owen (1961, 1962) and Sargent (1974) have taken samples and reported frequencies of swettaria. Most of these samples have come from the vicinities of industrial cities, where the frequency of swettaria may exceed 90 per cent, though two rural localities in Massachusetts have yielded samples with frequencies between 4 and 10 per cent (Owen, 1962; Sargent, 1974). The origins of the melanic forms in both Old and New World populations are believed to be as recurrent mutants which had low fitness on the clean and lichen-covered tree limbs and trunks of pre-industrial woodlands.

The earliest specimens of swettaria were collected rather late in the history of industrial development. The first was taken near Philadelphia in 1906, but the form was not collected in Chicago until 1935 and near New York City until 1948, though it was known from nearby New Jersey by 1920 and in upstate New York (Ithaca) in 1931 (Owen, 1961). It was probably overlooked in the large cities for some time.

In Britain, the dominance of the modern carbonaria form of betularia is believed to have evolved since melanics appeared around the middle of the last century, but whether by selection for modifiers of the original mutant allele or, as seems more likely, because the original allele was replaced by another having greater penetrance is not known (Sheppard, 1967: 128-129). 
Because melanism seems to have evolved more recently in North American cognataria than in European populations of betularia, I hoped to find populations of cognataria in which the allele for swettaria was still very rare and might not yet have evolved dominance. At the same time, Prof. Sheppard suggested that the carbonaria allele be introduced into the genetic background of such populations to see if the dominance of carbonaria would break down, as Kettlewell has reported (1965) in crosses with rural Canadian material. Both hopes were unfulfilled, for swettaria appears to be completely dominant even in populations where its frequency is 1 per cent, and the carbonaria phenotype retains its complete dominance through three generations of backcrossing to stocks from these same populations. The purpose of this paper is to give the evidence for these conclusions and to document the present frequencies of swettaria in the central Appalachians.

\section{Materials AND MEthods}

All samples were taken at light traps. In 1966 these were 15- and 40watt Black Light (BL) fluorescent traps of various designs. In 1967 a Robinson trap with a 100-watt mercury vapour (MV) bulb was also used, and in subsequent years this trap was used exclusively. The samples contained over 98 per cent males, a common occurrence in light traps, and those females that entered the trap were nearly always freshly-eclosed and unmated (see Clarke and Sheppard, 1963). For breeding, virgin females were taken from the MV trap in the morning and placed with individual males in net bags outdoors. My method is like that described by Kettlewell

TABLE 1

Phenotype frequencies in Biston b. cognataria in south-western Virginia

\begin{tabular}{|c|c|c|c|c|c|c|c|c|}
\hline Locality & Year & Month & Sex & swett. & ins. $^{5}$ & typ. & Total & $\begin{array}{c}\text { Per cent } \\
\text { swett. }\end{array}$ \\
\hline \multirow{3}{*}{$\begin{array}{c}\text { Blacksburg } \\
\text { and PF }\end{array}$} & 1966 & VI-X & both & 11 & ns* & 988 & 999 & $1 \cdot 1$ \\
\hline & 1967 & VI-IX & male & 7 & 3 & 650 & 660 & $1 \cdot 3$ \\
\hline & & & female & 2 & 0 & 20 & 22 & \\
\hline \multirow[t]{2}{*}{ PF } & 1969 & VIII & male & 0 & 0 & 81 & 81 & 0 \\
\hline & & & female & 0 & 0 & 3 & 3 & \\
\hline \multirow[t]{2}{*}{ IR } & 1975 & VII & male & 1 & 0 & 133 & 134 & 0.7 \\
\hline & & & female & 0 & 0 & 1 & 1 & \\
\hline \multirow[t]{2}{*}{ IR } & 1976 & VII & male & 2 & 0 & 86 & 88 & $2 \cdot 2$ \\
\hline & & & female & 0 & 0 & 1 & 1 & \\
\hline \multirow[t]{2}{*}{ MLBS } & 1968 & VII & male & 6 & 0 & 129 & 135 & 4.2 \\
\hline & & & female & 0 & 0 & 7 & 7 & \\
\hline MLBS & 1969 & VII & male & 6 & 0 & 187 & 193 & $3 \cdot 1$ \\
\hline \multirow[t]{2}{*}{ MLBS } & 1970 & VII- & male & 2 & 0 & 100 & 102 & $2 \cdot 0$ \\
\hline & & VIII & female & 0 & 0 & 2 & 2 & \\
\hline \multirow[t]{2}{*}{ MLBS } & 1972 & VII- & male & 15 & 1 & 561 & 577 & $2 \cdot 6$ \\
\hline & & VIII & female & 0 & 0 & 9 & 9 & \\
\hline \multirow[t]{2}{*}{ MLBS } & 1974 & VII- & male & 17 & 1 & 650 & 668 & $2 \cdot 8$ \\
\hline & & VIII & female & 2 & 0 & 12 & 14 & \\
\hline MLBS & 1976 & $\begin{array}{l}\text { VII- } \\
\text { VIUI }\end{array}$ & male & 5 & 0 & 136 & 141 & 3.5 \\
\hline & & & & & & & & \\
\hline $\begin{array}{l}\text { Blacksburg, } \\
\text { MLBS, }\end{array}$ & $\begin{array}{l}6-1976 \\
8-1976\end{array}$ & $\begin{array}{l}\mathrm{n}= \\
\mathrm{n}=\end{array}$ & $\begin{array}{l}989 \\
848\end{array}$ & $\begin{array}{l}\text { swett. }=23 \\
\text { swett. }=53\end{array}$ & $\begin{array}{l}(1 \\
(2\end{array}$ & $\begin{array}{l}\text { er ce } \\
\text { er ce }\end{array}$ & $\begin{array}{l}0.2 \text { per } \\
0.4 \text { per }\end{array}$ & $\begin{array}{l}\text { cent) } \\
\text { cent) }\end{array}$ \\
\hline
\end{tabular}

* Not scored 
(1973: Appendix A), except that I reared the larvae in plastic boxes throughout.

Females of the carbonaria form of betularia were supplied by Prof. P. M. Sheppard in 1966, and Blacksburg cognataria were used for the backcrosses. All of the 1974 broods were reared from material collected at the Mountain Lake Biological Station, Giles County, Virginia.

In addition to swettaria, North America populations of cognataria contain intermediate melanics, usually grouped together as "insularia" after the usage of Kettlewell (1973). In fact the typical cognataria resembles one of these insularia forms, ins. ${ }^{2}$ or ins. $^{3}$ (Kettlewell, 1973: plate 9.1). The darkest of the intermediates, and the easiest to classify has a dark background evenly speckled with white scales (Category 3 of Owen, 1962). It resembles ins. ${ }^{5}$ of Kettlewell (1973) and is so designated in this paper.

\section{Results}

Samples: The compositions of the samples are given in table 1, and the topographic relationships among the collecting localities are shown in the fig. All samples from the Blacksburg region (including Prices Fork and

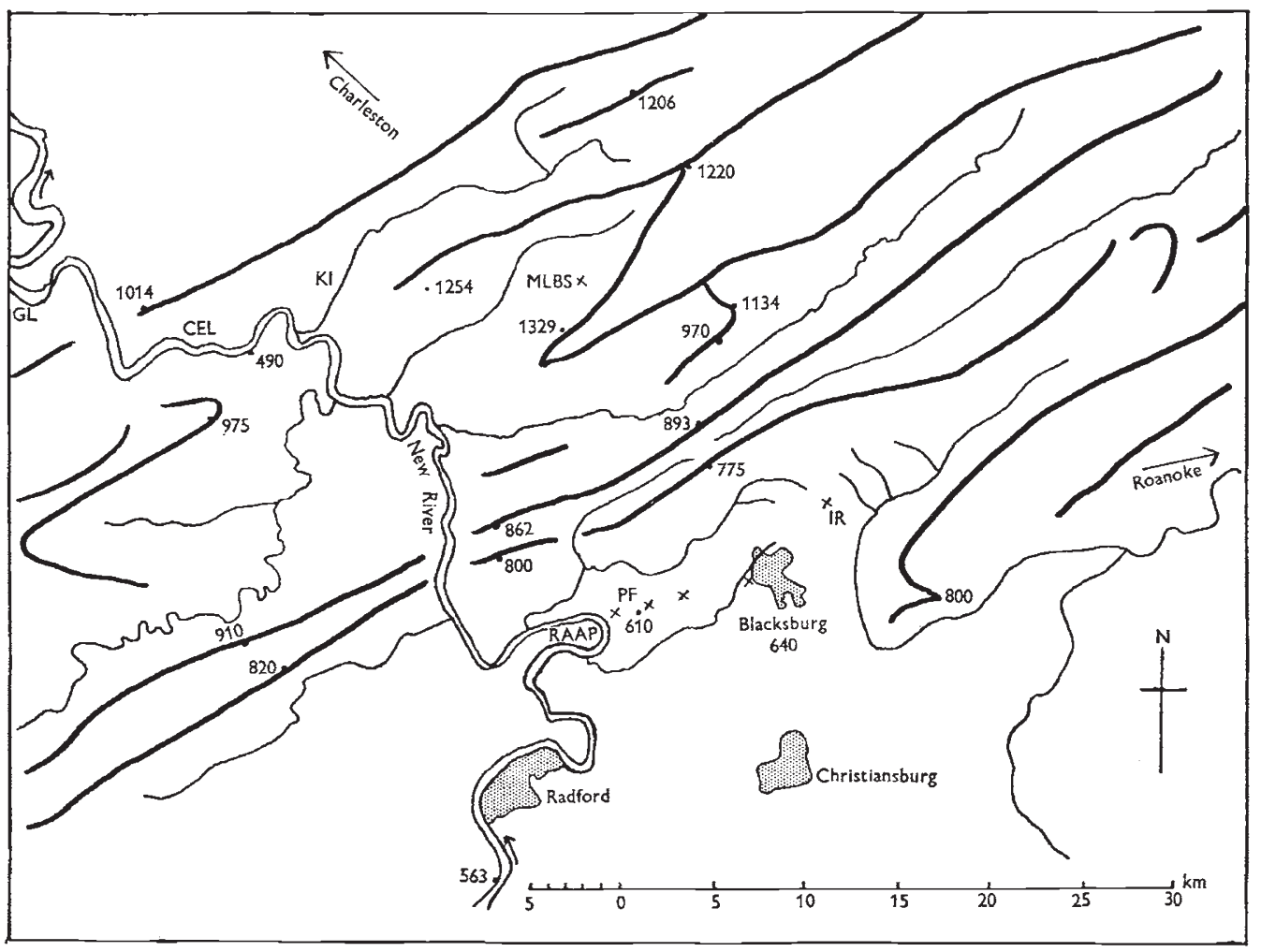

FIG.--Topographical relationships of collecting localities. $\mathbf{x}=$ localities, CEL $=$ Celco, $\mathrm{GL}=$ Glen Lyn, $\mathrm{IR}=$ Indian Run, $\mathrm{KI}=$ Kimballton, MLBS $=$ Mountain Lake Biological Station, PF $=$ Prices Fork, RAAP $=$ Radford Army Ammunition Plant. Heavy lines are mountain ridges. Spot elevations are in metres. 
Indian Run) are homogeneous (pooling 1969-76: $\chi^{2}{ }_{(2)}=1 \cdot 82 ; \mathrm{P}>0.30$ ) and together they give an estimate of the frequency of swettaria of 1.2 per cent \pm 0.2 per cent. The localities lie at elevations between 610 and $670 \mathrm{~m}$ in rolling countryside of mixed woods and farmland. Males of cognataria were caught hundreds of metres from the nearest woods, betularia males may fly several kilometres in a night (Bishop, 1972), and according to Kettlewell (1973) the newly-hatched larvae disperse as aerial plankton. The similarity of the habitat around Blacksburg and the lack of barriers to dispersal are probably responsible for the homogeneity of swettaria frequencies over the $13 \mathrm{~km}$ separating the extreme localities.

At the Mountain Lake Biological Station (MLBS), $18 \mathrm{~km}$ north of Blacksburg and $500 \mathrm{~m}$ higher, all samples are homogeneous (pooling 196970: $\left.\chi^{2}{ }_{(4)}=0-71 ; \mathrm{P}>0.95\right)$ and give an estimate of swettaria frequency of 2.9 per cent \pm 0.4 per cent. MLBS is surrounded by deciduous forest (chiefly oaks, Quercus; maple, Acer; and hickory, Carya) and is separated from the Blacksburg region by three wooded ridges, 800 to $1000 \mathrm{~m}$, and two valleys, 550 to $650 \mathrm{~m}$ above sea level. The frequency of swettaria is different in the two sampling regions $\left(2 \times 2\right.$ contingency table: $\chi^{2}{ }_{(1)}=13.7 ; \mathrm{P}<$ $0.001)$.

Genetics of cognataria: The results of crosses of cognataria are given in table 2. They confirm that swettaria is dominant to typical. This conclusion follows both from the fully melanic phenotype of heterozygous

TABLE 2

Broods of Biston b. cognataria showing inheritance of melanic and typical forms ( $M L B S, 1974$ )

\begin{tabular}{|c|c|c|c|c|c|}
\hline \multirow{3}{*}{$\begin{array}{c}\text { Brood } \\
\text { no. }\end{array}$} & \multicolumn{5}{|l|}{ 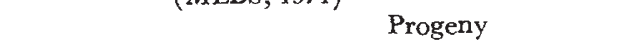 } \\
\hline & $\begin{array}{c}\text { Parental } \\
\text { phenotypes }\end{array}$ & \multicolumn{2}{|c|}{ swettaria } & \multicolumn{2}{|c|}{ typical } \\
\hline & fermale male & fcrmale & male & fernale & male \\
\hline 7403 & typ. $\times$ typ. & 0 & 0 & 3 & 9 \\
\hline 7404 & typ. $x$ typ. & 0 & 0 & 11 & 12 \\
\hline 7405 & typ. $\times$ typ. & 0 & 0 & 10 & 8 \\
\hline 7401 & typ. $\times$ swett. & 4 & 4 & 4 & 9 \\
\hline 7408 & typ. $\times$ swett. & 10 & 12 & 8 & 11 \\
\hline \multirow[t]{2}{*}{7406} & swett. $\times$ swett. & 7 & 6 & 3 & 0 \\
\hline & & \multicolumn{2}{|c|}{ ins. $^{5}$} & \multicolumn{2}{|c|}{ typical } \\
\hline 7402 & typ. $\times$ ins. ${ }^{5}$ & 2 & 1 & 3 & 1 \\
\hline
\end{tabular}

swettaria taken in the wild and of those reared in broods 7401 and 7408 , and from the uniform melanism of the swettaria progeny of brood 7406, in which $2 / 3$ of the melanics should be heterozygous and the remainder homozygous.

Brood 7402 shows that ins. ${ }^{5}$ is at least partly dominant in the population at MLBS. In British betularia, both paler insularia (Clarke and Sheppard, 1964) and darker ones (Lees, 1968) are controlled by alleles of the carbonaria locus, and they are dominant to typical, though recessive to carbonaria itself.

Backcrosses of carbonaria to Virginia material: Brood 68 (table 3) shows clearcut segregation of carbonaria and typical moths, with no breakdown in dominance, despite the presence of around 87 per cent of Blacksburg cognataria gene complex. In crosses with Canadian typicals, Kettlewell (1965) got a partial breakdown of dominance in the presence of a comparable 
proportion of Canadian gene complex, and a complete breakdown (continuous variation) in the next backcross generation. The heterozygous male parent of that fourth generation (Kettlewell, 1973; plate 19.1) is clearly a far from perfect carbonaria. The progeny of my brood 68 are comparable in ancestry to that male. The costal margins of the hind-wings of melanics in brood 68 are marked with the pattern of typicals, but this pattern is found in some carbonaria taken in Britain and was present in the carbonaria parent of brood 66. Thus it does not represent any change in the phenotypic expression of the carbonaria allele as a result of the backcrosses. In any event, the costal margin of the hind-wing is not visible when the wings are held naturally and will not have been subject to selection for modification.

TABLE 3

Backcross broods of carbonaria into typical cognataria

\begin{tabular}{|c|c|c|c|c|c|}
\hline \multirow{3}{*}{$\begin{array}{c}\text { Brood } \\
\text { no. }\end{array}$} & \multirow{2}{*}{\multicolumn{2}{|c|}{$\begin{array}{c}\text { Parental } \\
\text { phenotypes }\end{array}$}} & \multicolumn{3}{|c|}{ Progeny } \\
\hline & & & $c a r b$ & & typical \\
\hline & females & male & female & male & female male \\
\hline 66 & $\begin{array}{l}\text { carbonaria } \\
\text { (Cheshire) }\end{array}$ & $\begin{array}{c}\text { typical } \\
\text { (Blacksburg) }\end{array}$ & & (all co & onaria) \\
\hline 67 & $\begin{array}{c}\text { carbonaria } \\
\text { (ex Brood 66) }\end{array}$ & $\begin{array}{c}\text { typical } \\
\text { (Blacksburg) }\end{array}$ & $\begin{array}{c}14 \\
\text { (pupae: }\end{array}$ & $\begin{array}{c}28 \\
152 \mathrm{fe}\end{array}$ & $\begin{array}{cc}7 & 40 \\
\text { ales, } 154 & \text { males }\end{array}$ \\
\hline 68 & $\begin{array}{c}\text { carbonaria } \\
\text { (ex Brood 67) }\end{array}$ & $\begin{array}{c}\text { typical } \\
\text { (Blacksburg) }\end{array}$ & $\begin{array}{l}67 \\
\text { (pupae: }\end{array}$ & $\begin{array}{c}69 \\
166 \mathrm{fe}\end{array}$ & $\begin{array}{cc}62 & 69 \\
\text { ales, } 174 \text { males) }\end{array}$ \\
\hline
\end{tabular}

\section{Discussion}

\section{(i) Present frequencies of swettaria}

Although the status of swettaria in the central Appalachians 75 or 80 years ago is not known, two facts suggest that it is an industrial melanic: (1) melanics were not known before the beginning of this century in any North American populations; (2) on Mount Mitchell (2025 m), some 240 $\mathrm{km}$ south-west of Blacksburg along the Appalachian mountains, melanics are still apparently absent (J. B. Sullivan, pers. comm.).

If one accepts this conclusion, then the questions are, what has caused a rise in the frequency of swettaria in south-western Virginia, and why is the frequency higher in the seemingly unspoiled montane forest at Mountain Lake than in the vicinity of a minor pollution source like Blacksburg? There may be gene flow from areas of higher swettaria frequency, or there may be subtle effects of air pollution at MLBS and less so in Blacksburg that have increased the relative fitness of swettaria in some way not primarily related to lichen cover and the colour of tree limbs and trunks.

The nearest areas with high frequencies of swettaria are probably Charleston, West Virginia, $150 \mathrm{~km}$ north-west of MLBS, and the Roanoke Valley, $35 \mathrm{~km}$ east of Blacksburg, and gene flow would have to be much greater from the north-west to account for a higher frequency of swettaria at MLBS than at Blacksburg.

The local pollution sources in the New River Valley to the west of MLBS (Kimballton, Celco, Glen Lyn: see fig.) may support higher frequencies of swettaria than the surrounding mountains do, but the effects of 
the pollution are very local. $\mathrm{SO}_{2}$ and nitrogen oxides from RAAP have affected tree growth near by (Stone and Skelly, 1974) but they do not seem to have had any effect on swettaria frequency near Blacksburg, a few kilometres away. Thus, neither gene flow from distant industrial areas nor the effects of local pollution sources can explain the difference in swettaria frequency at MLBS and Blacksburg.

There remains the possibility of subtle effects of polluted air from more distant urban areas. Ozone and other oxidants have increased two- to three-fold in the Appalachians between 1962 and 1975-76, especially at higher elevations (Hayes, 1976). Melanics may have a physiological advantage in mildly polluted conditions (Sargent, 1971, 1974; Lees and Creed, 1975). Bishop et al. (1975) doubt the importance of non-visual selection, but although differential bat predation may favour melanics (Whittle et al., 1976), the maintenance of low frequencies of melanics in rural areas is still a puzzle.

\section{(ii) Backcrosses of carbonaria into North American material}

The failure of a breakdown in dominance of the carbonaria phenotype when backcrossed for three generations to Blacksburg stock contrasts strikingly with the results of Kettlewell (1965, 1973). There are two differences between Kettlewell's backcrosses and mine. My typical material came from a population in which swettaria was present (though at low frequency: l per cent) and dominant in expression, Kettlewell's from populations in Western Canada with no melanics (Kettlewell, pers. comm.). The population in Blacksburg may already have modifiers that support dominance of the carbonaria allele, although there is no evidence that North American populations of cognataria have evolved dominance by selection for such modifiers. The phenotypes of swettaria and carbonaria are indistinguishable, but even if the alleles for swettaria and carbonaria were at the same locus there would be no rcason to expect the same modifiers in both British and North American populations (see Ford, 1955, on Triphaena comes).

In addition, I used a melanic female in every generation, and Kettlewell used males in at least some generations (see Kettlewell, 1973: plate 19.1). If there is no crossing over in Biston females (cf. the geometrid genus Cidaria: Suomalainen, 1965), and if the dominance modifiers are on the same chromosome as the locus for melanism, then my melanic females would have been passing on the whole British chromosome whereas Kettlewell's males would have been producing gametes recombinant for British and Canadian alleles at many loci. The genetic evidence says only that the modifiers are dominant but nothing about linkage (Kettlewell, 1973: 316-317). Partial linkage of the modifiers with the carbonaria locus would have made the evolution of dominance far easier than if they were completely unlinked.

The swettaria allele appears to have been dominant since it first arose, since the earliest specimens are as black as modern ones. In Britain it seems that the first melanic allele to be selected was one producing a partially melanic phenotype, and that a second and more penetrant allele later replaced it (Sheppard, 1967). There is no way to tell whether the earlier allele had dominant expression, as opposed to lesser penetrance. The history of melanism in North American cognataria does not include such an 
imperfect melanic and thus will not help with the problem of the evolution of dominance in British betularia.

Acknowledgments. - I appreciated the comments of the late Professor P. M. Sheppard and Drs J. A. Bishop, James Murray and T. D. Sargent on an earlier draft. Drs H. B. D. Kettlewell and J. B. Sullivan kindly supplied unpublished information. I am also grateful to Drs James Murray and James Riopel for permission to trap at the Mountain Lake Biological Station, and to Carlton Hite and Dr M. P. Levin for help with the sampling, as well as to the landowners who permitted my trap on their land. Drs J. G. Franclemont, C. L. Remington and F. H. Rindge were most helpful in guiding me through the collections under their care at Cornell University, Yale University and the American Museum of Natural History, respectively.

\section{REFERENCES}

BISHOP, J. A. 1972. An experimental study of the cline of industrial melanism in Biston betularia (L.) (Lepidoptera) between urban Liverpool and rural North Wales. J. Anim. Ecol., 41, 209-243.

BISHOP, J. A., COOK, L. M., MUGGLeton, J. AND SEAWARD, M. R. D. 1975. Moths, lichens and air pollution along a transect from Manchester to North Wales. J. Appl. Ecol., 12, 83-98.

Clarke, C. A., AND SHEPPARD, P. M. 1963. Frequencies of the melanic forms of the moth Biston betularia (L.) on Deeside and in adjacent areas. Nature, 198, 1279-1282.

CLARKE, C. A., AND SHEPPARD, P. M. 1964. Genetic control of the melanic form insularia of the moth Biston betularia (L.). Nature, 202, 215-216.

FORD, E. B. 1955. Moths. Collins, London.

HAYES, E. M. 1976. The effects of an oxidant air pollution regime in southwestern Virginia on eastern white pine (Pinus strobus L.). M.S. Thesis, Virginia Polytechnic Institute and State University, Blacksburg, Va.

KetTleWEll, H. B. D. 1965. Insect survival and selection for pattern. Science, 148, 12901295.

KetTlewell, H. B. D. 1973. The Evolution of Melanism. Clarendon, Oxford.

LEES, D. R. 1968. Genetic control of the melanic form insularia of the peppered moth Biston betularia L. Nature, 220, 1249-1250.

LEES, D. R., AND CREED, E. R. 1975. Industrial melanism in Biston betularia: the rôle of selective predation. J. Anim. Ecol., 44, 67-83.

owen, D. F. 1961. Industrial melanism in North American moths. Amer. Nat., 95, 227-233.

OWEN, D. F. 1962. The evolution of melanism in six species of North American geometrid moths. Ann. Ent. Soc. Amer., 55, 695-703.

RINDGE, F. H. 1975. A revision of the New World Bistonini (Lepidoptera Geometridae). Bull. Amer. Mus. Nat. Hist., 156, 69-156.

SARgent, T. D. 1971. Melanism in Phigalia titea (Cramer) (Lepidoptera: Geometridae). J. N.Y. Ent. Soc., 79, 122-129.

SARGENT, T. D. 1974. Melanism in moths of central Massachusetts (Noctuidae, Geometridae). F. Lep. Soc., 28, 145-152.

SHEPPARD, P. M. 1967. Natural Selection and Heredity, 3rd ed. Hutchinson, London.

STONE, L. L., AND SKELLY, J. M. 1974. The growth of two forest tree species adjacent to a periodic source of air pollution. Phytopathology, 64, 773-778.

suomalainen, E. 1965. On the chromosomes of the geometrid moth genus Cidaria. Chromosoma (Berl.), 16, 166-184.

WHITTLE, P. D. J., ClARKE, C. A., SHEPPARD, P. M.; AND BISHOP, J. A. 1976. Further studies on the industrial melanic moth Biston betularia (L.) in the northwest of the British Isles. Proc. R. Soc. Lond., (B), 194, 367-380. 